\title{
Pengaruh Pemahaman Diri Terhadap Sikap Mandiri Siswa Pada SMP Negeri 3 Monta
}

\author{
Nur Syariful Amin \\ STKIP Bima \\ nursyarifulamin bk@stkipbima.ac.id
}

\begin{abstract}
Abstrak
Kurangnya sikap mandiri para remaja sekarang ini akhirnya berdampak pada perkembangan yang serba menurun dari berbagai aspek, mulai dari kreativitas, motivasi belajar, bahkan sampai kepada tidak mengenali apa minat dan bakat yang sebenarnya mereka miliki yang harus dikembangkan.

Maka sikap mandiri yang seharusnya adalah sebagai kemampuan diri seseorang untuk mengahasilkan sesuatu yang positif dalam rangka mengembangkan potensi
\end{abstract} yang dimiliki.

Kemampuan para remaja untuk mengenali minat bakat dan potensi yang dimiliki merupakan tuntutan dari tugas perkembangan pada masa remaja, sehingga diharapkan ketika meningkat pada usia perkembangan berikutnya, individu tersebut sudah tidak mengalami kebingungan lagi.

Pemahaman Diri menjadi salah satu factor yang dapat meningkatkan kemampuan para remaja dalam hal ini adalah siswa untuk memiliki sikap mandiri. Artinya semakin tinggi kemampuan mengenali potensi-potensi yang terpendam yang ada didalam dirinya, maka ia akan mengalami kemajuan dalam hal memacu kreativitas dan prestasi dalam berbagai bidang.

Penelitian ini bertujuan untuk mengetahui Apakah Ada Pengaruh pemahaman diri terhadap sikap mandiri siswa pada SMP Negeri 3 Monta Kabupaten Bima Tahun Pelajaran 2017-2018, adapun yang dijadikan sample dalam penelitian ini adalah siswa kelas 2 yang berjumlah 24 orang. Penelitian ini termasuk penelitian kuantitatif karena menggunakan rancangan empiris dan gejala yang diamati telah ada secara wajar tampa harus memanipulasi terlebih dahulu Teknik pengumpulan data dalam penelitian ini menggunakan dokumentasi untuk mengetahui prestasi belajar siswa dan angket untuk mengetahui perencanaan karir. Keduanya dianalisis dengan menggunakan analisis statistik deskriptif melalui rumus korelasi product moment

Berdasarkan perhitungan korelasi product moment, diperoleh nilai yaitu $r x y=0,743$. Jika dilihat nilai $r$ tabel dengan $n=24$, taraf signifikansi $5 \%=$ 0,404 dan taraf signifikansi $1 \%=0,515$. Sehingga jika rxy dibandingkan dengan $r$ tabel, maka rxy > $r$ tabel. Dari hasil tersebut dapat disimpulkan bahwa Ho ditolak dan $\mathrm{Ha}$ diterima. Sehingga kesimpulannya adalah ada pengaruh pemahaman diri terhadap sikap mandiri siswa pada SMP Negeri 3 Monta Kabupaten Bima Tahun Pelajaran 2017-2018.

Pemahaman diri yang objektif menuntut orang untuk mengetahui siapa diri seseorang yang sebenarnya, kemampuan dan minat yang dimiliki dan hal-hal yang disenangi maupun yang tidak, setelah itu diharapkan bisa mengetahui benar akan dirinya sehingga nantinya seseorang bisa melihat kelebihan dan kekurangan yang dimiliki, bisa mengembangkan sikap positif dengan memahami kelebihankelebihan yang dimiliki dan melahirkan keyakinan yang kuat untuk bisa berbuat segala sesuatu serta bereaksi positif terhadap kelemahan-kelemahan yang dimiliki supaya tidak menimbulkan rasa rendah diri maupun rasa sulit menyesuaikan diri sehingga secara tidak langsung dengan pemahaman diri diharapkan akan meningkatkan kepercayaan diri dan sikap mandiri.

\section{Kata kunci: Pemahaman diri, Sikap mandiri}

Nur Syariful Amin 
Volume 2 Nomor 2

November 2019

E-ISSN : 2614-3585

\section{PENDAHULUAN}

\section{A. Latar Belakang}

Dengan semakin majunya zaman seiring dengan berkembangnya ilmu pengetahuan dan teknologi, persaingan dalam kehidupan semakin ketat. Disatu sisi kemajuan teknologi berdampak pada semakin mudah dan canggihnya system komunikasi informasi sehingga tidak ada lagi yang namanya batas ruang dan jarak, berbagai alat kebutuhan manusia semakin canggih dan serba instant. Namun dari segi mentalitas manusia terutama para remaja, semakin canggihnya ilmu pengetahuan dan teknologi justru semakin menunjukkan sikap ketergantungan terhadap suatu benda dan semakin sulit untuk mengenali jati diri.

Kurangnya sikap mandiri para remaja sekarang ini akhirnya berdampak pada perkembangan yang serba menurun dari berbagai aspek, mulai dari kreativitas, motivasi belajar, bahkan sampai kepada tidak mengenali apa minat dan bakat yang sebenarnya mereka miliki yang harus dikembangkan.

Menurut kamus besar bahasa indonesia terbitan Departemen Pendidikan dan Kebudayaan, kemandirian adalah hal atau keadaan dapat berdiri sendiri tanpa bergantung kepada orang lain. Dari pengertian di atas perlu diterangkan lebih lanjut, bahwa dalam kenyataannya tidak ada manusia yang mampu hidup berdiri sendiri tanpa bergantung kepada orang lain. Manusia adalah makhluk sosial yang tidak lepas dari kehidupan bermasyarakat.

Maka sikap mandiri yang seharusnya adalah sebagai kemampuan diri seseorang untuk mengahasilkan sesuatu yang positif dalam rangka mengembangkan potensi yang dimiliki.

Kemampuan para remaja untuk mengenali minat bakat dan potensi yang dimiliki merupakan tuntutan dari tugas perkembangan pada masa remaja, sehingga diharapkan ketika meningkat pada usia perkembangan berikutnya, individu tersebut sudah tidak mengalami kebingungan lagi.

Pemahaman Diri menjadi salah satu factor yang dapat meningkatkan kemampuan para remaja dalam hal ini adalah siswa untuk memiliki sikap mandiri. Artinya semakin tinggi kemampuan mengenali potensi-potensi yang terpendam yang ada didalam dirinya, maka ia akan mengalami kemajuan dalam hal memacu kreativitas dan prestasi dalam berbagai bidang.

Kondisi obyektif di SMP Negeri 3 Monta yang peneliti amati saat melakukan observasi pendahuluan ketika PPL, terdapat beberapa siswa yang mengalami kekurangan dalam hal sikap mandiri, sikap tersebut ditunjukkan dengan malas mengerjakan PR, tidak belajar disaat tidak ada guru yang mengajar, dll. Hal ini nampaknya disebabkan karena kurangnya kemampuan mereka untuk mengenali dan memahami jati diri mereka sendiri. Untuk mendukung dan memperkuat dugaan sementara yang ada dalam benak peneliti, maka peneliti sangat tertarik sekali untuk melakukan penelitian dengan judul " Pengaruh Pemahaman Diri terhadap Sikap Mandiri siswa pada SMP Negeri 3 Monta Tahun Pelajaran 2017-2018".

Adapun yang menjadi tujuan dari penelitian ini adalah : "Untuk mengetahui ada tidaknya Pengaruh Pemahaman Diri terhadap Sikap Mandiri siswa"?

\section{KAJIAN PUSTAKA}

\section{A. Pemahaman Diri}

Pemahaman diri merupakan salah satu proses yang harus dilakukan untuk membentuk konsep diri, dengan pemahaman diri yang didasarkan dengan sikap positif akan memunculkan konsep diri yang positif juga dimana hal itu akan berpengaruh pada kepercayaan diri yang tinggi. 
Lindenfield (1997) menjelaskan salah satu ciri khusus orang yang mempunyai kepercayaan diri adalah pemahaman diri, dimana orang yang percaya diri secara batin juga sangat sadar akan dirinya, tidak terus-menerus merenungi diri sendiri tetapi secara teratur memikirkan perasaan, pikiran dan prilaku mereka dan mereka selalu ingin tahu bagaimana pendapat orang lain tentang diri mereka

Pemahaman diri yang objektif akan membuat seseorang mengerti akan dirinya, termasuk kelemahan dan kelebihan yang dimiliki serta bisa bersikap positif dalam menanggapi kelemahan dan kelebihan yang ada. Menurut Loekmono (dalam Kartono, 1985) tujuan mengenal dan memahami diri sendiri bukannya untuk membuat orang menjadi kecewa setelah mengetahui bagaimana kepribadian dirinya, tetapi diharapakan agar setelah mengenal dan memahami dirinya sendiri seseorang dapat menerima kenyataan yang ada lalu berusaha dengan yang ada pada dirinya untuk mengembangkan pribadinya agar sehat dan memiliki karakteristik yang positif.

Pemahaman diri yang objektif menuntut orang untuk mengetahui siapa diri seseorang yang sebenarnya, kemampuan dan minat yang dimiliki dan hal-hal yang disenangi maupun yang tidak, setelah itu diharapkan bisa mengetahui benar akan dirinya sehingga nantinya seseorang bisa melihat kelebihan dan kekurangan yang dimiliki, bisa mengembangkan sikap positif dengan memahami kelebihan-kelebihan yang dimiliki dan melahirkan keyakinan yang kuat untuk bisa berbuat segala sesuatu serta bereaksi positif terhadap kelemahan-kelemahan yang dimiliki supaya tidak menimbulkan rasa rendah diri maupun rasa sulit menyesuaikan diri sehingga secara tidak langsung dengan pemahaman diri diharapkan akan meningkatkan kepercayaan diri

Sebaliknya individu tidak tahu bagaimana ia dihadapkan orang lain tanpa ada informasi atau masukan dari lingkungan maupun orang lain. Dalam kehidupan sehari-hari secara tidak langsung individu telah menilai dirinya sendiri. Penilaian terhadap diri sendiri itu meliputi watak dirinya, orang lain dapat menghargai dirinya atau tidak, dirinya termasuk orang yang berpenampilan menarik, cantik atau tidak. Seperti yang dikemukakan Hurlock (1990:58) memberikan pengertian tentang konsep diri sebagai gambaran yang dimiliki orang tentang dirinya. Konsep diri ini merupakan gabungan dari keyakinan yang dimiliki individu tentang mereka sendiri yang meliputi karakteristik fisik, psikologis, sosial, emosional, aspirasi dan prestasi.

Menurut William D. Brooks bahwa konsep diri adalah pandangan dan perasaan kita tentang diri kita (Rakhmat, 2005:105). Sedangkan Centi (1993:9) mengemukakan konsep diri (self-concept) tidak lain tidak bukan adalah gagasan tentang diri sendiri, konsep diri terdiri dari bagaimana kita melihat diri sendiri sebagai pribadi, bagaimana kita merasa tentang diri sendiri, dan bagaimana kita menginginkan diri sendiri menjadi manusia sebagaimana kita harapkan.

\section{B. Sikap Mandiri}

Menurut Kamus Besar Bahasa Indonesia terbitan DEPEN dan Kebudayaan Kemandirian adalah hal atau keadaan dapat berdiri sendiri tanpa bergantung kepada orang lain. Pengertian di atas perlu diterangkan lebih lanjut, karena dalam kenyataannya tidak ada manusia yang mampu hidup berdiri sendiri tanpa bergantung kepada orang lain.

Manusia adalah makhluk sosial yang tidak lepas dari kehidupan bermasyarakat, mereka saling menghubungkan sikap, tingkah laku dan perbuatan, saling memberi dan menerima sehingga meskipun ukurannya sedikit tetap saja memerlukan bantuan orang lain. Bukankah dalam perjalannan 
hidup manusia apa yang dimakan bukan hasil tanamannya sendiri, bukan masakan sendiri, pakaian yang dikenakan juga bukan dari kapas tanamannya sendiri, bukan memintal dan menjahit sendiri. Ketika sakit juga memerlukan bantuan orang lain, terlebih ketika meninggal dunia juga tidak mampu masuk kuburan sendiri.

Jadi jelaslah bagaimanapun juga manusia tetap memerlukan jasa dan pertolongan orang lain dalam kehidupannya. Persoalannya tinggal apakah ia memberikan imbalan atau kompensasi ketika membutuhkan apapun keperluan dari orang lain, dan apakah imbalan itu dari hasil jerih payahnya sendiri?

Kiranya inilah unsur penting yang mempunyai relevansi kuat dengan kemandirian seseorang .

Maka agar lebih sesuai dengan realita kehidupan, kemandirian itu kita artikan sebagai kemampuan diri seseorang untuk mengahasilkan "sesuatu" sebagai imbalan atau nilai tukar terhadap apa yang dibutuhkan, yang dikonsumsi, dimiliki dan dinikmati. Pada umumnya orang dengan mudah akan mengatakan bahwa mereka yang telah memiliki penghasilan sendiri untuk mencukupi keperluan hidupnya, meraka itulah orang-orang yang telah mandiri.

Kemandirian memang dimulai dari sikap, adapun factor yang mempengaruhi sikap mandiri itu banyak namun dalam pembahasan ini akan dibatasi tiga factor yaotu fsktor ekonomi, keasaan dalam keluarga dan linfgkungan masyarakat.

Orang yang berada pada ekonomi sulit biasanya akan cenderung segera bangkirt sebagai reaksi atas keterbatasan kesejahteraan yang ada padanya. Mereka tidak segan melakukan apa saja demi menghasilkan uang, bahkan dikerjakan tanpa mengenal waktu. Situasi dan kondisi ekonominya akan memberikan gemblengan menjadikan insane yang selektif dan hemat dalam pengeluaran pembelanjaan. Mereka lebih terbiasa dan mampu mangatasi berbagai kesulitan hidup, sebagai dampak positifnya mereka cenderung menjadi lebih cepat memiliki sikap mandiri daripada anggota keluarga yang tumbuh dalam keadaan ekonomi yang serba kecukupan.

Kebiasaan dalam keluarga juga dapat berpengaruh terhadap sikap kemandirian seseorang. Banyak orang tua yang telah mampu memanjakan anak-anaknya tetapi akhiranya tidak mampu menanamkan sikap kemandirian. Sebenarnya pendidikan sederhana tentang kemandirian kepada anak dapat dilakukakn oleh orang tua dengan cara memberikan tugas-tugas yang harus diselesaikan dalam waktu tertentu. Hal terpenting bahwa proses pendidikan kemandirian dapat berhasil manakala dapat terwujdnya transformasi pendelegasian tanggungjawab dari orang tua kepada anaknya.

Seorang kepala rumah tangga juga perlu mendidik kemandirian kepada istrinya dengan cara mengkondisikan agar istrinya tidak larut dalam pola hidup boros, konsumtif namun sebaliknya bagaimana seorang istri dapat mengelola pembelanjaan sebaik-baiknya sehingga tidak "lebih besar pasak daripada tiaynag". Pemanfatan secara optimal barang yang yang tersedia. Melatih berusaha untuk mendapatkan income keluarga, meskipun urusan ma'isah adalah sepebuhnya tanggung jawab suami, namun secara umum hal ini akan berpengaruh terhadap pembiasaan sikap hidup mandiri badi seluruh anggota keluarga ternasuk anak remaja.

Para remaja yang solat subuhnya saja masih menggantungkan dibangunkan oleh orang tua maka remaja ini cenderung lamban mempunyai sikap mandiri.

\section{Pengaruh Pemahaman Diri terhadap Sikap Mandiri Siswa}




\section{GUIDING WORLD JURNAL BIMBINGAN \\ DAN KONSELING}

Volume 2 Nomor 2

November 2019

E-ISSN : 2614-3585

DOI: 1033627

Pemahaman diri merupakan salah satu proses yang harus dilakukan untuk membentuk konsep diri, dengan pemahaman diri yang didasarkan dengan sikap positif akan memunculkan konsep diri yang positif juga dimana hal itu akan berpengaruh pada kepercayaan diri yang tinggi.

Lindenfield (1997) menjelaskan salah satu ciri khusus orang yang mempunyai kepercayaan diri adalah pemahaman diri, dimana orang yang percaya diri secara batin juga sangat sadar akan dirinya, tidak terus-menerus merenungi diri sendiri tetapi secara teratur memikirkan perasaan, pikiran dan prilaku mereka dan mereka selalu ingin tahu bagaimana pendapat orang lain tentang diri mereka

Pemahaman diri yang objektif menuntut orang untuk mengetahui siapa diri seseorang yang sebenarnya, kemampuan dan minat yang dimiliki dan hal-hal yang disenangi maupun yang tidak, setelah itu diharapkan bisa mengetahui benar akan dirinya sehingga nantinya seseorang bisa melihat kelebihan dan kekurangan yang dimiliki, bisa mengembangkan sikap positif dengan memahami kelebihan-kelebihan yang dimiliki dan melahirkan keyakinan yang kuat untuk bisa berbuat segala sesuatu serta bereaksi positif terhadap kelemahan-kelemahan yang dimiliki supaya tidak menimbulkan rasa rendah diri maupun rasa sulit menyesuaikan diri sehingga secara tidak langsung dengan pemahaman diri diharapkan akan meningkatkan kepercayaan diri dan sikap mandiri.

Sikap mandiri sangat penting dimiliki oleh siswa, agar dalam bersikap dan melaksanakan tugas tidak tergantung pada orang lain dan bertanggung jawab terhadap apa yang telah dikerjakannya. Siswa dengan kemandirian yang tinggi, akan berusaha untuk mendapatkan dan menggunakan segala fasihtas dan sumber belajar dengan sebaik-baiknya. Sikap mandiri siswa dalam mengenakan tugas harus dipupuk sedini mungkin, karena dengan sikap mandiri dapat menunjukkan inisiatif, berusaha untuk mengejar prestasi, mempunyai rasa percaya diri.

\section{METODE PENELITIAN}

Penelitian ini memakai rancangan empiris, karena gejala yang diamati telah ada secara wajar tanpa harus memanipulasi terlebih dahulu (Furchan, 1982). Sementara itu, ditinjau dari sifat penelitian, maka penelitian ini bersifat penelitian deskriptif-eksplanatoris, yakni menggambarkan data dari variabel-variabel yang diteliti kemudian dilanjutkan dengan menjelaskan hubungan serta pengaruh antara variabel yang akan diteliti.

Sebelum menentukan sampel, maka populasi penelitian harus ditetapkan terlebih dahulu. Menurut Suharsimi Arikunto (1998:115), populasi adalah keseluruhan subyek penelitian. Sedangkan menurut Husaini Usman (1995:181) pengertian populasi adalah semua nilai baik hasil perhitungan maupun pengukuran baik kuantitatif maupun kualitatif, daripada karakteristik tertentu mengenai sekelompok objek yang lengkap dan jelas.

Dari pengertian di atas, dapat disimpulan bahwa populasi adalah semua individu dari keseluruhan subjek yang jelas dan mempunyai ciri yang sama yang hendak dikenai dalam penelitian. Dalam penelitian ini yang menjadi populasi penelitian adalah siswa kelas 2 SMP Negeri 3 Monta Tahun Pelajaran 2017 / 2018 yang berjumlah 110 orang siswa

Menurut Suharsimi Arikunto (1998:120), bahwa apabila dalam pengambilan sampel yang jumlah subjeknya besar (lebih dari 100 orang) maka dapat diambil antara $10-15 \%$ atau $20-25 \%$ atau lebih. Dengan demikian sampel sebesar 20\%-nya yaitu 24 orang siswa. 
Menurut Arikunto (1986), instrumen adalah alat pengumpulan data ketika peneliti menggunakan sesuatu metode pengumpulan data. Sehubungan dengan itu, maka instrumen pengumpulan data dalam penelitian ini adalah data Angket

Untuk melihat Pengaruh Pemahaman Diri terhadap Sikap Mandiri Siswa digunakan rumus Korelasi Product Moment.

\section{HASIL PENELITIAN DAN PEMBAHASAN}

Berdasarkan data yang diperoleh selanjutnya dilakukan analisis data dan pengujian hipotesis penelitian. Oleh karena itu disiapkan tabel untuk memudahkan perhitungan korelasi product moment.

Tabel Perhitungan Korelasi Product Moment

\begin{tabular}{|c|c|c|c|c|c|}
\hline No & $\mathrm{X}$ & $\mathrm{Y}$ & $\mathrm{X}^{2}$ & $\mathrm{Y}^{2}$ & $\mathrm{XY}$ \\
\hline 1 & 45 & 43 & 2025 & 1849 & 1935 \\
\hline 2 & 40 & 41 & 1600 & 1681 & 1640 \\
\hline 3 & 42 & 44 & 1764 & 1936 & 1848 \\
\hline 4 & 41 & 45 & 1681 & 2025 & 1845 \\
\hline 5 & 40 & 42 & 1600 & 1764 & 1680 \\
\hline 6 & 39 & 40 & 1521 & 1600 & 1560 \\
\hline 7 & 38 & 42 & 1444 & 1764 & 1596 \\
\hline 8 & 44 & 41 & 1936 & 1681 & 1804 \\
\hline 9 & 42 & 45 & 1764 & 2025 & 1890 \\
\hline 10 & 43 & 45 & 1849 & 2025 & 1935 \\
\hline 11 & 40 & 42 & 1600 & 1764 & 1680 \\
\hline 12 & 35 & 38 & 1225 & 1444 & 1330 \\
\hline 13 & 38 & 39 & 1444 & 1521 & 1482 \\
\hline 14 & 39 & 42 & 1521 & 1764 & 1638 \\
\hline 15 & 45 & 44 & 2025 & 1936 & 1980 \\
\hline 16 & 44 & 45 & 1936 & 2025 & 1980 \\
\hline 17 & 40 & 43 & 1600 & 1849 & 1720 \\
\hline 18 & 39 & 42 & 1521 & 1764 & 1638 \\
\hline 19 & 44 & 45 & 1936 & 2025 & 1980 \\
\hline 20 & 42 & 45 & 1764 & 2025 & 1890 \\
\hline 21 & 38 & 41 & 1444 & 1681 & 1558 \\
\hline 22 & 44 & 45 & 1936 & 2025 & 1980 \\
\hline 23 & 42 & 43 & 1764 & 1849 & 1806 \\
\hline 24 & 41 & 42 & 1681 & 1764 & 1722 \\
\hline & $\sum \mathrm{X}$ & $\sum \mathrm{Y}$ & $\sum \mathrm{X}^{2}$ & $\sum \mathrm{Y}^{2}$ & $\sum \mathrm{XY}$ \\
\hline Jumlah & 985 & 1024 & 40581 & 43786 & 42117 \\
\hline & & & & & \\
\hline
\end{tabular}

Selanjutnya subtitusi nilai pada tabel di atas pada persamaan korelasi product moment yaitu sebagai berikut :

$$
\begin{aligned}
r_{X Y} & =\frac{N \sum X Y-\left(\sum X\right)\left(\sum Y\right)}{\sqrt{\left.\left\{N \sum X^{2}-\left(\sum X\right)^{2}\right\} N \sum Y^{2}-\left(\sum Y\right)^{2}\right\}}} \\
r_{X Y} & =\frac{24.42117-985.1024}{\sqrt{\{24.40581-970225\}\{24.43786-1048576\}}}
\end{aligned}
$$




$$
\begin{aligned}
r_{X Y} & =\frac{1010808-1008640}{\sqrt{\{973944-970225\}\{1050864-1048576\}}} \\
r_{X Y} & =\frac{2168}{\sqrt{\{3719\}\{2288\}}} \\
r_{X Y} & =\frac{2168}{\sqrt{8509072}} \\
r_{X Y} & =\frac{2168}{2917,031368} \\
r_{X Y} & =0,743
\end{aligned}
$$

Sebelum pengujian hipotesis, terlebih dahulu merumuskan hipotesis nihil (Ho) dan hipotesis alternatif (Ha).

Berdasarkan perhitungan korelasi product moment, diperoleh nilai yaitu rxy $=0,743$. Jika dilihat nilai $r$ tabel dengan $n=24$, taraf signifikansi $5 \%=0,404$ dan taraf signifikansi $1 \%=0,515$. Sehingga jika rxy dibandingkan dengan $\mathrm{r}$ tabel, maka rxy > r tabel. Dari hasil tersebut dapat disimpulkan bahwa Ho ditolak dan Ha diterima yang menyatakan ada pengaruh pemahaman diri terhadap sikap mandiri siswa pada SMP Negeri 3 Monta Kabupaten Bima Tahun Pelajaran 2009/2010.

\section{Pembahasan}

Pemahaman diri yang objektif menuntut orang untuk mengetahui siapa diri seseorang yang sebenarnya, kemampuan dan minat yang dimiliki dan hal-hal yang disenangi maupun yang tidak, setelah itu diharapkan bisa mengetahui benar akan dirinya sehingga nantinya seseorang bisa melihat kelebihan dan kekurangan yang dimiliki, bisa mengembangkan sikap positif dengan memahami kelebihankelebihan yang dimiliki dan melahirkan keyakinan yang kuat untuk bisa berbuat segala sesuatu serta bereaksi positif terhadap kelemahan-kelemahan yang dimiliki supaya tidak menimbulkan rasa rendah diri maupun rasa sulit menyesuaikan diri sehingga secara tidak langsung dengan pemahaman diri diharapkan akan meningkatkan kepercayaan diri dan sikap mandiri.

Sebagaimana hasil penelitian yang berdasarkan perhitungan korelasi product moment, diperoleh nilai yaitu rxy $=0,743$. Jika dilihat nilai $r$ tabel dengan $\mathrm{n}=24$, taraf signifikansi $5 \%=0,404$ dan taraf signifikansi $1 \%=0,515$. Sehingga jika rxy dibandingkan dengan $r$ tabel, maka rxy $>r$ tabel. Dari hasil tersebut dapat disimpulkan bahwa Ho ditolak dan Ha diterima yang menyatakan ada pengaruh pemahaman diri terhadap sikap mandiri siswa pada SMP Negeri 3 Monta Kabupaten Bima Tahun Pelajaran 2009/2010.

Sikap mandiri sangat penting dimiliki oleh siswa, agar dalam bersikap dan melaksanakan tugas tidak tergantung pada orang lain dan bertanggung jawab terhadap apa yang telah dikerjakannya. Siswa dengan kemandirian yang tinggi, akan berusaha untuk mendapatkan dan menggunakan segala fasihtas dan sumber belajar dengan sebaik-baiknya. Sikap mandiri siswa dalam mengenakan tugas harus dipupuk sedini mungkin, karena dengan sikap mandiri dapat menunjukkan inisiatif, berusaha untuk mengejar prestasi, mempunyai rasa percaya diri. 


\section{Kesimpulan}

Berdasarkan hasil pengujian dan pembahasan hasil penelitian yang telah diuraikan pada BAB IV, maka dapat diambil kesimpulan bahwa Secara umum pemahaman diri berpengarhu terhadap sikap mandiri siswa, hal ini berdasarkan perhitungan korelasi product moment, diperoleh nilai yaitu rxy $=0,743$. Jika dilihat nilai $\mathrm{r}$ tabel dengan $\mathrm{n}=24$, taraf signifikansi $5 \%=0,404$ dan taraf signifikansi $1 \%=0,515$. Sehingga jika rxy dibandingkan dengan $r$ tabel, maka rxy > $\mathrm{r}$ tabel. Dari hasil tersebut dapat disimpulkan bahwa Ho ditolak dan Ha diterima

\section{Saran- Saran}

Berdasarkan kesimpulan penelitian yang telah dikemukakan di atas, maka diajukan beberapa saran yang berhubungan dengan pola asuh orang tua terhadap perkembangan moral remaja yakni sebagai berikut :

1. Kepada pihak sekolah agar meningkatkan dan mnegajarkan kepada ada caracara memahami diri supaya anak kedepannya memiliki sikap mandiri lebih dini.

2. Untuk pihak kampus STKIP Bima agar lebih mengembangkan diri dan lebih profesional lagi dalam kegiatan penyelenggaraan pendidikan, dan hasil penelitian bisa dijadikan sebagai rujukan sekaligus sebagai perbandingan dalam mengatasi persoalan siswa yang kurang percaya diri.

3. Kepada pihak peneliti lain agar senantiasa berusaha keras dalam mengambil langkah-langkah kongkrit dalam merancang instrumen penelitian pada tempat tertentu, guna mendapatkan sebuah hasil yang baik dalam mengambil data, peneliti harus berangkat dengan teori demi terwujudnya hasil yang maksimal. 


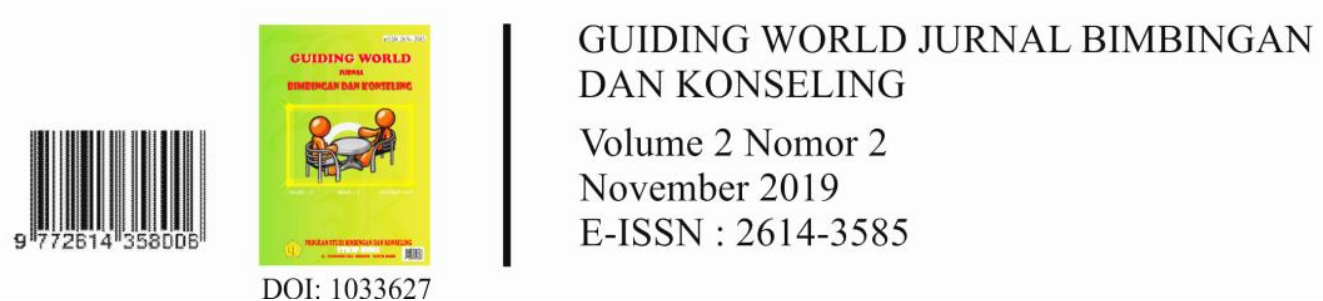

\section{DAFTAR RUJUKAN}

Arikunto, Suharsimi. 2002. Prosedur Penelitian (Suatu Pendekatan Praktek). Jakarta: Rineka Cipta.

Azwar, Saifuddin. 2001. Metode Penelitian. Yogyakarta: Pustaka Pelajar Offset. Hurlock, B. Elizabeth. 1990. Psikologi Perkembangan. Jakarta : Erlangga.

Anorogo, Panji. Sudantoko, Djoko. 2002, Koperasi, Kewirausahaan, dan Usaha Kecil, Rineka Cipta, Jakarta.

Geoffrey G. Meredith, et al. 2000, Kewirausahaan Teori dan Praktek. Pustaka Binaman Pressindo, Jakarta.

Jakarta.

Harefa, Andreas., Inovasi Kewirausahaan (Kecerdasan Emosi Wirausaha) http://www.ekafood.com/cerdasemosi.htm

Tedjasutisna, Ating 2004. Memahami Kewiraushaan. Armico, Bandung.

Wijandi, Soesarsono, 1988, Pengantar Kewiraswastaan, Sinar Baru,Bandung. 